\title{
URGENSI PENGEMBANGAN BAHAN AJAR GEOGRAFI BERBASIS KEARIFAN LOKAL
}

\author{
Ardyanto Tanjung, Muhammad Fahmi \\ Universitas Negeri Malang \\ E-mail: ardyanto.tanjung.fis@um.ac.id
}

\begin{abstract}
Abstrak: Artikel ini bertujuan untuk memberi gambaran peran Pengembangan bahan ajar Geografi. Salah satu permasalahan pembelajaran geografi dewasa ini adalah ketika materi cenderung hafalan tanpa menyadari fakta kearifan local yang bisa menjadi materi yang penting dipahami peserta didik. Implementasi Kurikulum 2013 mengisyaratkan pembelajaran yang mengangkat kearifan lokal sebagai materi yang perlu dikembangkan khususnya pada pembelajaran Geografi.Terdapat beberapa langkah belajar yang bisa diterapkan dalam pembelajaran Geografi, langkah belajar tersebut diharapkan dapat merangsang peserta didik dalam melatih kepekaan mengidentifikasi lingkungan dan kewilayahan dimana peserta didik tinggal. Untuk mencapai tujuan tersebut diperlukan identifikasi masalah, sejumlah langkah kerja sehingga materi ajar dapat menjadi jawaban permasalahan di sekitar peserta didik.
\end{abstract}

Kata kunci: Pengembangan bahan ajar, Geografi, kearifan local, kurikulum 2013

\section{PENDAHULUAN}

Bahan ajar merupakan bagian penting dalam proses pembelajaran. Bahan ajar dijadikan sebagai salah satu sumber informasi materi yang penting bagi guru maupun siswa. Keberadaan bahan ajar sangat penting karena bahan ajar merupakan komponen yang harus dikaji, dicermati, dipelajari dan dijadikan bahan materi yang akan dikuasai oleh siswa dan sekaligus dapat memberikan pedoman untuk memperlajarinya (Hernawan, dkk. 2008).

Bahan ajar yang baik menurut sunarya (2005) harus memenuhi persyaratan sebagai berikut: 1) Bahan ajar disusun menurut kurikulum yang berlaku,
2) Bahan ajar disusun oleh para ahli bidangnya, 3) Bahan ajar tersebut hendaknya dilengkapi dengan kegiatankegiatan yang menunjang ketrampilan berfikir, ketrampilan proses, sikap dan nilai - nilai, 4) Bahan ajar hendaknya mencerminkan aspek materi penyajian, bahan serta keterbacaan yang sesuai dengan tingkat perkembangan peserta didik.

Keberadaan bahan ajar akan membantu guru dalam mencapai tujuan pembelajaran. Oleh karena itu sangat penting bagi guru untuk memiliki kompetensi mengembangkan bahan ajar yang baik sesuai de-ngan persyaratan dan 
kebutuhan yang diperlukan, sehingga materi pem-belajaran dapat tersampaikan dengan baik, serta siswa pun memiliki aktivitas belajar yang cukup baik (Hernawan dkk, 2008).

Saat ini bahan ajar yang dipakai oleh guru belum memperhatikan kondisi siswa dan lingkungannya, karena pada umumnya guru menggu-nakan bahan ajar komersial sebagai pegangan dalam pembelajaran. Hal tersebut menyebabkan guru terlalu tergantung pada bahan ajar komersial. Ketergantungan guru terhadap bahan ajar komersial sangat tinggi. Guru lebih memilih untuk membeli bahan ajar dari penerbit dibandingkan dengan membuat bahan ajar sendiri. Alasannya bervariasi, mulai dari kepraktisan, tidak adanya waktu dan kurangnya dana dalam membuat bahan ajar. Padahal idealnya seorang guru harus mampu mengembangkan bahan ajar untuk menunjang pembelajaran, karena pengembangan bahan ajar merupakan salah satu upaya dalam meningkatkan mutu pendidikan.

Dalam pengembangan bahan ajar guru merupakan pionir dalam pengembangannya. Hal tersebut diatur dalam UU No. 14 tahun 2005 tentang guru dan dosen, bahwa guru harus memiliki komitmen untuk meningkatkan mutu pendidikan.

Faktor yang mendasari permasalahan guru dalam mengembangkan bahan ajar selain alasan yang diuraikan sebelumnya adalah kemampuan guru dalam mengembangkan bahan ajar masih kurang. Oleh karena itu perlu upaya peningkatan kemampuan guru dalam mengembangkan bahan ajar.

Berdasarkan kajian yang dipaparkan pada bagian sebelumnya serta hasil observasi dan wawancara, maka permasalahan yang dapat diidentifikasi adalah:

a. Mayoritas Guru belum pernah mengembangkan bahan ajar Geografi

b. Guru tidak tahu prosedur dalam pengembangan bahan ajar

c. Bahan ajar tidak dianggap penting karena terbiasa menggunakan bahan ajar penerbit

d. Belum ada sosialisasi atau pelatihan tentang pengembangan bahan ajar

\section{TUJUAN}

Penulisan artikel ini bertujuan untuk mengidentifikasi permasalahan pengembangan bahan ajar Geografi, serta materi pembelajarannya. Pengalaman belajar siswa yang salah tentu akan 
Ardyanto Tanjung, Muhammad Fahmi. Urgensi Pengembangan

Bahan Ajar Geografi Berbasis Kearifan Lokal

membuat kebermaknaan belajar menjadi sedikit bahkan merosot hingga sampai diragukan sumbangan Geografi dalam membekali pengetahuan, kemampuan, dan keterampilan maupun kompetensi peserta didik. Pada hal, pembelajaran Geografi diharapkan melengkapi anak didik dengan nilai-nilai, sikap, dan pengetahuan untuk menjadi warga negara Indonesia hidupnya lebih baik, sejahtera, bahagia, bermanfaat, dan bertanggung jawab (Rifai, 1972:27).

Dengan mengidentifikasi permasalahnya, diharapkan timbul pemecahan masalah sebagai upaya perbaikan dan mengembalikan materi Geografi yang bermanfaat dan bermakna bagi peserta didik. Apabila hal ini dapat terwujud maka pembelajaran Geografi akan semakin berkualitas dalam meningkatkan keyakinkan masyarakat dan pemerintah tentang pentingnya pembelajaran Geografi bagi peserta didik, dan pentingnya bagi dunia pendidikan. Pembahasan pada makalah ini difokuskan pada cara-cara dalam meningkatkan kecerdasan ruang melalui materi dan langkah belajar.

\section{METODE}

\begin{tabular}{lccc}
\multicolumn{1}{c}{ Metode } & yang & dipakai & dalam \\
penulisan makalah & ini & adalah \\
dokumentasi. Pada & awalnya & penulis \\
mengindentifikasi & \multicolumn{2}{c}{ permasalahan } \\
pembelajaran & geografi & melalui
\end{tabular}
pengamatan bahan ajar dan wawancara, serta menganalisis secara lengkap hasil tersebut secara deskriptif.

\section{PEMBAHASAN}

\section{Bahan Ajar Geografi}

Bahan ajar merupakan sebuah elemen penting yang mendukung pencapaian tujuan pembelajaran. Bahan ajar merupakan faktor eksternal yang mendukung motivasi internal dalam belajar (Hermawan, 2009). Menurut Biggs dan Tefler (dalam Dakir dkk, 2000) diantara motivasi belajar siswa ada yang diperkuat dari acara-acara pembelajaran. Motivasi instrumental, sosial, dan berprestasi siswa dapat dimunculkan oleh guru dengan memunculkan cara-cara baru dalam pembelajaran. Motivasi instrumental dapat dimunculkan dengan menggunakan bahan ajar yang tepat sehingga siswa mampu meningkatkan motivasi belajarnya. 
Bahan ajar itu sendiri menurut Dick \& Carey (1996) merupakan seperangkat materi/substansi pelajaran (teaching material) yang disusun secara sistematis, menampilkan sosok utuh dari kompetensi yang akan dikuasai oleh peserta didik dalam kegiatan pembelajaran.

Penggunaan bahan ajar yang tepat akan mampu menstimulus siswa agar giat belajar sehingga, mempermudah guru dalam menyampaikan materi pembelajaran. Bahan ajar yang disusun secara baik dan lengkap yang berarti memiliki unsure materi dan media maka kondisi belajar siswa akan lebih optimal. Penambahan ilustrasi juga akan memberikan dorongan kepada siswa untuk belajar secara mandiri.

Menurut Sungkono, dkk (2003) bahan ajar merupakan seperangkat bahan yang memuat materi atau isi pembelajaran yang didesain untuk mencapai tujuan pembelajaran. Suatu bahan ajar memuat materi, pesan atau isis mata pelajaran yang berupa ide fakta, konsep, prinsip, kaidah, atau teori yang tercakup dalam mata pelatihan sesuai disiplin ilmu. oleh karena itu apabila bahan ajar disusun secara baik dan lengkap maka bahan ajar akan sangat baik untuk digunakan siswa dalam proses belajar secara mandiri.

\section{Bahan Ajar Berbasis Kearifan Lokal}

Masyarakat Indonesia sudah sepatutnya untuk kembali kepada jati diri mereka melalui pemaknaan kembali dan rekonstruksi nilai-nilai luhur budaya mereka. Dalam kerangka itu, upaya yang perlu dilakukan adalah menguak makna substantif kearifan lokal. Sebagai misal, keterbukaan dikembangkan dan kontekstualisasikan menjadi kejujuran dan seabreg nilai turunannya yang lain. Kehalusan diformulasi sebagai keramah-tamahan yang tulus.

Kearifan lokal merupakan salah satu wujud budaya yang diciptakan oleh nenek moyang bangsa Indonesia. Dalam kearifan local mengandung nilai-nilai luhur yang dapat digunakan dalam membangun karakter bangsa. Bagaimana pun dan betapa pun, secara jujur harus diakui bahwa yang berasal dari budaya Barat itu tidak seluruhnya tidak baik. Sebaliknya, yang ada dan muncul dari rumah kita sendiri itu pun tidak kontan pasti baik. Yang bernama kebaikan dan ketidakbaikan selalu ada di mana-mana. Hanya saja, yang pasti, arus budaya yang datang dari luar atau sebut saja dari Barat itu demikian kuatnya menghantam budaya lokal, sehingga sangat dimungkinkan bahwa budaya lokal, 
Ardyanto Tanjung, Muhammad Fahmi. Urgensi Pengembangan

Bahan Ajar Geografi Berbasis Kearifan Lokal

kearifan lokal, local wisdom, indeginous wisdom kita akan segera mati. Di samping, sebagai tali pengikat yang menjadikan golongan- golongan dalam masyarakat menjadi suatu organisasi hukum.

Ada dua hal yang paling tidak, harus dipikirkan untuk dilakukan terkait dengan fenomena di atas. Pertama, sebut saja upaya eksternal, pemilik budaya lokal, kearifan lokal, (local wisdom, indeginous wisdom) mesti menyikapi secara arif budaya 'asing' yang mau masuk. Kedua, sebut saja upaya internal, budaya lokal, kearifan lokal, (local wisdom,indigenous wisdom) diangkat kembali ke permukaan, sehingga tampak nilai-nilai kultural dari balik simbol-simbol yang ada.(Surasmi, 2012)

Upaya internal dengan mengangkat kembali nilai-nilai keraifan lokal ke permukaan dapat dilakukan dengan pendidikan. Pendidikan tak hanya dapat dilakukan secara formal oleh guru di sekolah melainkan, dapat pula dengan belajar secara secara mandiri dengan bahan ajar yang dikembangkan oleh guru yang memuat nilai-nilai luhur dalam kearifan lokal.
Teori-teori belajar yang menjelaskan dan mendukung bagi kemungkinan kesesuaian bahan ajar yang disusun berdasarkan kondisi dan fenomena lokal antara lain teori perkembangan kognitif Piaget. Dalam hal ini, Piaget (dalam Ginn, 2001:2) menjelaskan bahwa perkembangan kognitif itu sendiri merupakan suatu usaha penyesuaian diri terhadap lingkungan melalui proses asimilasi dan akomodasi. Asimilasi merupakan suatu tindakan pasif dalam membangun pengetahuan utama yang melibatkan penafsiran peristiwa dalam hubungannya dengan struktur kognitif yang ada. Sedangkan, akomodasi merupakan suatu pengetahuan yang baru yang mengacu pada perubahan struktur kognitif yang disebabkan oleh lingkungan.

Dalam hal pengembangan bahan ajar, Dick dan Carey (1996: 228), mengajukan hal-hal berikut untuk diperhatikan, yakni: (1) memperhatikan motivasi belajar yang diinginkan, (2) kesesuaian materi yang diberikan, (3) mengikuti suatu urutan yang benar, (4) berisikan informasi yag dibutuhkan, dan (5) adanya latihan praktek, (6) dapat memberikan umpan balik, (7) tersedia tes yang sesuai dengan materi yang 
diberikan, (8) tersedia petunjuk untuk tindak lanjut ataupun kemajuan umum pembelajaran (9) tersedia petunjuk bagi peserta didik untuk tahap-tahap aktivitas yang dilakukan, dan (10) dapat diingat dan ditransfer.

Berdasarkan model pengembangan yang diajukan Dick dan Carey sudah jelas bahwa bahan ajar haruslah berisi informasi yang dibutuhkan oleh siswa. Nilai-nilai luhur dalam kearifan local merupakan informasi yang penting dalam membangun karakter siswa. Sehingga, diperlukan sebuah bahan ajar yang berbasis kearifan lokal untuk membangun karakter bangsa.

\section{KESIMPULAN DAN SARAN}

Melalui pembahasan diatas, ditemukan fakta bahwa perlu adanya usaha dari pendidik untuk mengembangkan bahan ajar agar sesuai dengan kebutuhan dan mengangkat kearifan di wilayah peserta didik tinggal. Hal tersebut akan membuat pembelajaran menarik, Berdasarkan paparan diatas maka solusi yang ditawarkan untuk mengatasi permasalahan tersebut adalah memberikan wawasan tentang guru yang ideal, memberikan pemahaman mengenai kondisi bahan ajar saat ini, dan memberikan penyuluhan dan pemahaman tentang pengembangan bahan ajar Geografi kurikulum 2013 agar mengangkat materi kearifan lokal.

\section{DAFTAR RUJUKAN}

Daulay, Pardamean. 2012. Membangun Masyarakat Harmonis Berbasis Kearifan Lokal: Dari Keseragaman Menuju Keberagaman (online) (http://artikelut.wordpress.com) Diakses, 5 Maret 2014.

Dick, Walter dan Lou Carey. (1996). The Systematic Design of Instruction. New York: Longman

Ginn, Wanda Y. Jean Piaget-Intellectual Development. Available at (http// www.sk.com.br/skpiaget.html) diakses, 5 Maret 2014.

Haryanto dkk. 2009. Sistem Sosial Budaya Indonesia. Jakarta: Universitas Terbuka.

Hermawan, Asep Hery, dkk. 2009. Pengembangan Bahan Ajar (online) (http://file.upi.ac.id) Diakses, 5 Maret 2014.

Koentjaraningrat. 1984. Kebudayaan Mentalitas dan Pembangunan. Cetakan ke-11. Jakarta: Gramedia.

Susanti, Retno LR. 2012. Membangun Pendidikan Karakter Di Sekolah :Melalui Kearifan Lokal (online). (http://repository.usu.ac.id) Diakses, 5 Maret 2014. 